soon learn what plants could be utilized for this purpose, employing either cultivated species or wild plants obtained from seed scattered in waste places.

\title{
FEDERAL PROTECTION TO AMERICAN AGRICULTURE AND HORTICULTURE FROM INVASION BY FOREIGN INSECT PESTS
}

By $\mathrm{J}_{\text {ACOB }}$ Kotixsky, Honolulu, Havaii.

(Withdrawn for publication elsewhere.)

It was impossible to publish the following paper in regular sequence, owing to a failure to submit the manuscript in due time. The discussion relating thereto follows.

ED.

\section{LIFE HISTORY OF THE STRIPED CUCUMBER BEETLE WITH A BRIEF ACCOUNT OF SOME EX- PERIMENTS FOR ITS CONTROL}

By T. J. HeadLe, Manhattan, Kan.

In this paper it is purposed to give briefly the results of a study of the striped cucumber beetle, undertaken at the New Hampshire station for the purpose of clearing up certain doubtful points in its life history, its action under local conditions, and the practicability of the common remedial measures. Credit is due Prof. Sanderson for constant aid and encouragement.

\section{Life History}

Egg. In 1907 the first eggs discovered were laid by a caged beetle on July 2 d, but it was not until July 16 th that they were found in the field. Eggs were last taken in the cages the 7th of August, and oviposition in the field appeared to have ceased some time before. The egg-laying period, therefore, occupies about one month in New Hampshire.

The eggs are deposited singly or, with equal frequency, in groups, in the soil, usually just beneath the surface, but sometimes on the surface or, again, a considerable distance down. The variation seems to be largely dependent upon the compactness and moisture of the ground. When it was dry and cracked, the beetle was likely to deposit her eggs on the moist soil in some crevice, but if damp and com- 